\title{
Problems regarding the tropospheric $\mathrm{O}_{3}$ residual method and its interpretation in Fishman et al. (2003)
}

A. T. J. de Laat and I. Aben

National Institute for Space Research (SRON) Utrecht, The Netherlands

Received: 15 September 2003 - Accepted: 11 November 2003 - Published: 14 November 2003

Correspondence to: A. T. J. de Laat (a.t.j.de.laat@sron.nl)

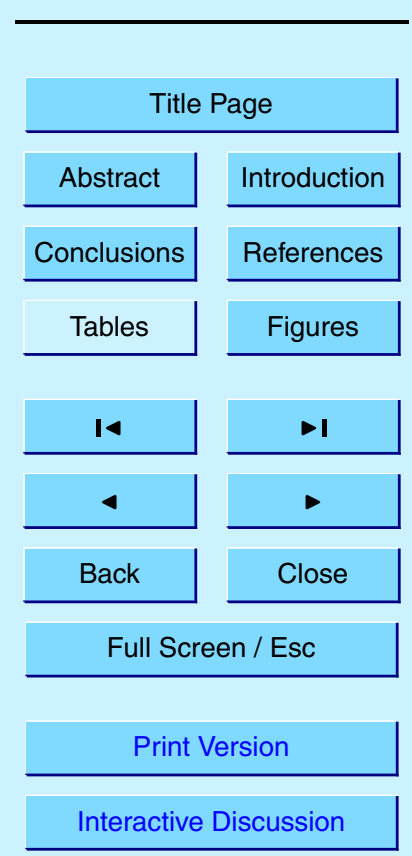

Problems regarding the tropospheric $\mathrm{O}_{3}$ residual method

A. T. J. de Laat and

I. Aben

(C) EGU 2003 


\section{Abstract}

In this article we will show that the Total Ozone Residuals (TOR) method as presented by Fishman et al. (2003) contains an erroneous assumption, due to which the TOR as presented in this article reflects mainly a tropospheric $\mathrm{O}_{3}$ climatology (Logan, 1999), 5 scaled to the layer between the surface and the tropopause height, rather than a satellite measured TOR. We will show that it is possible to obtain a tropospheric $\mathrm{O}_{3}$ column that is very similar to what is being presented in Fishman et al. (2003), solely based on the Logan (1999) tropospheric $\mathrm{O}_{3}$ climatology and an estimate for the tropopause heights without using satellite data. Furthermore, we will show that one of the interpretations of observed $\mathrm{O}_{3}$ variability (high TOR values over Southeast Asia) is not the result of pollution, but primarily of tropopause height variations. We suggest adjusting the method in such a way that the final retrieved TOR product becomes independent of the actual values of the Logan (1999) $\mathrm{O}_{3}$ climatology. The proposed adjustments are also more in line with the original methodology suggested by Fishman and Balok

15 (1999) in a previous paper. We furthermore show that the assumption that the stratospheric $\mathrm{O}_{3}$ column is nearly constant within a 5-day period is not always valid. This can introduce errors in the final TOR product, although we recognize that these errors may become small when averaging the TOR product over longer periods of time. However, we feel that a detailed study on this assumption is also needed.

\section{Introduction}

Over the last decade or so several methods have been developed to estimate the tropospheric $\mathrm{O}_{3}$ content from satellite observations (for example Hudson and Thompson, 1996; Kim et al., 1996; Ziemke et al., 1998; Fishman and Balok, 1999; Newchurch et al., 2003; Fishman et al., 2003). Observing tropospheric $\mathrm{O}_{3}$ from space is difficult, because the largest part of the total ozone column is found in the stratosphere, with tropospheric $\mathrm{O}_{3}$ contributing only a small part to the total $\mathrm{O}_{3}$ column. Most of
ACPD

3, 5777-5802, 2003

Problems regarding the tropospheric $\mathrm{O}_{3}$ residual method

A. T. J. de Laat and

I. Aben

(C) EGU 2003 
the $\mathrm{O}_{3}$ that (backscattered) sunlight has encountered along its path through the atmosphere is located in the stratosphere. As a result, most of the $\mathrm{O}_{3}$ information in the backscattered sunlight is stratospheric, not tropospheric, and any retrieval from the backscattered sunlight has a reduced sensitivity to the troposphere (Hasekamp and 5 Landgraf, 2002). In addition, clouds often obscure the observation of tropospheric $\mathrm{O}_{3}$ at ultra-violet and visible wavelengths. One commonly applied method is to use one instrument which measures total $\mathrm{O}_{3}$ columns and another instrument which measures stratospheric $\mathrm{O}_{3}$ profiles. Subtracting the stratospheric part from the total $\mathrm{O}_{3}$ column yields (at least in principle) a residual which is the tropospheric part This is also the 10 methodology followed by Fishman et al. (2003).

In this article we focus on two aspects of the retrieval of Total $\mathrm{O}_{3}$ Residuals (TOR, also known as Total Tropospheric $\mathrm{O}_{3}$ Columns or TTOC) as recently presented by Fishman et al. (2003). In Sect. 2 we show that the method applied to derive TOR columns should be interpreted as the monthly Logan (1999) climatology with daily 15 varying tropopause heights, with the differences between the daily TOMS total $\mathrm{O}_{3}$ column and the once-per-5-days SBUV total $\mathrm{O}_{3}$ column superimposed on it. In Sect. 3 we show that we can derive similar results as found in Fishman et al. (2003) using the Logan (1999) climatology and the tropopause height variations without making any use of satellite data. In Sect. 4 we also show that the interpretation of what is claimed in Fishman et al. (2003) as pollution observed over northern India and China during northern hemisphere summer is in fact predominantly the tropopause height variation between summer and winter. In Sect. 5 we suggest a slight adjustment that makes the TOR column dependent on the vertical distribution of $\mathrm{O}_{3}$ in the Logan (1999) climatology rather than on the actual $\mathrm{O}_{3}$ values of the climatology. The suggested adjustment 25 is also more in line with a previous publication on this topic (Fishman and Balok, 2003). In Sect. 6 we investigate the assumption in the Fishman et al. (2003) method that the stratospheric $\mathrm{O}_{3}$ column is nearly constant for a given 5 -day period. We show that the stratospheric $\mathrm{O}_{3}$ variability for a 5-day period is too large to be ignored. We end with a summary, discussion and recommendation section (Sect. 7).

\section{Problems regarding the tropospheric $\mathrm{O}_{3}$ residual method}

A. T. J. de Laat and

I. Aben

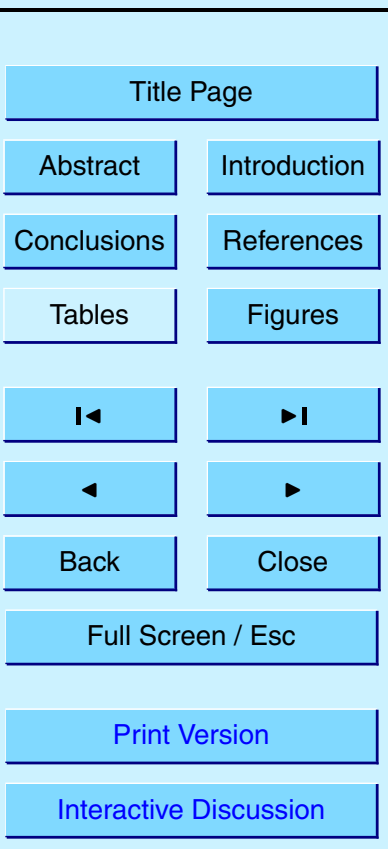




\section{Calculation of TOR}

The method described in Fishman et al. (2003) uses Total Ozone Monitoring Satellite (TOMS, 2003) measurements of the total $\mathrm{O}_{3}$ column and Solar Backscattered UltraViolet instrument (SBUV, 2003) stratospheric $\mathrm{O}_{3}$ profile measurements (Bhartia et al., 5 1996). Basically, the method subtracts the stratospheric $\mathrm{O}_{3}$ column from the total $\mathrm{O}_{3}$ column. The tropopause height for determining the separation between stratosphere and troposphere is obtained from NCEP 6-hourly gridded $\left(2.5^{\circ} \times 2.5^{\circ}\right)$ climate model analysis. One of the problems of this method is that an SBUV vertical $\mathrm{O}_{3}$ profile measurement for a particular site is available only once every 5 days. TOMS total $\mathrm{O}_{3}$ columns are available globally on a daily basis. In the Fishman et al. (2003) method it is therefore assumed that the total stratospheric $\mathrm{O}_{3}$ column amount does not change over a 5 day period. In Sect. 6 we will discuss this assumption further.

The SBUV $\mathrm{O}_{3}$ profile consists of 12 subcolumns between $0.3-1013 \mathrm{hPa}$. Subcolumns that could be (partly) tropospheric are layers $1(1013-253 \mathrm{hPa}, 0-10 \mathrm{~km})$, 15 layer $2(253-127 \mathrm{hPa} 10-14.5 \mathrm{~km})$ and layer $3(127-63.3 \mathrm{hPa} 14.5-19 \mathrm{~km}))$. The accuracy of the TOR product depends very much on the error and accuracy of the SBUV profile. According to Bhartia et al. (1996), the SBUV $\mathrm{O}_{3}$ profile is independent from the a priori information between $1-20 \mathrm{hPa}(30-50 \mathrm{~km})$. Outside of this region only the total column amounts $(1-0.3 \mathrm{hPa}$ and $20-1013 \mathrm{hPa})$ can be considered to be relatively free of a priori assumptions. Bhartia et al. (1996) concluded that the SBUV retrieval algorithm placed enhanced amounts of tropospheric ozone into the lower troposphere. Validation showed that only the SBUV total column between the surface and 20-30 hPa were in agreement with non-SBUV observed columns (Bhartia et al., 1996; Ziemke et al., 1998). Validation of the SBUV tropospheric $\mathrm{O}_{3}$ column layers showed that the tropospheric sub-columns do not agree with observations from radiosonde profiles (Fishman and Balok, 1999). The $\mathrm{O}_{3}$ column in layer 1 is too low; the $\mathrm{O}_{3}$ column in layer 3 is too high while the $\mathrm{O}_{3}$ column in layer 2 is comparable to the observed radiosonde $\mathrm{O}_{3}$ column. Moreover, Fishman and Balok (1999) claim that the total in-
ACPD

3, 5777-5802, 2003

Problems regarding the tropospheric $\mathrm{O}_{3}$ residual method

A. T. J. de Laat and

I. Aben

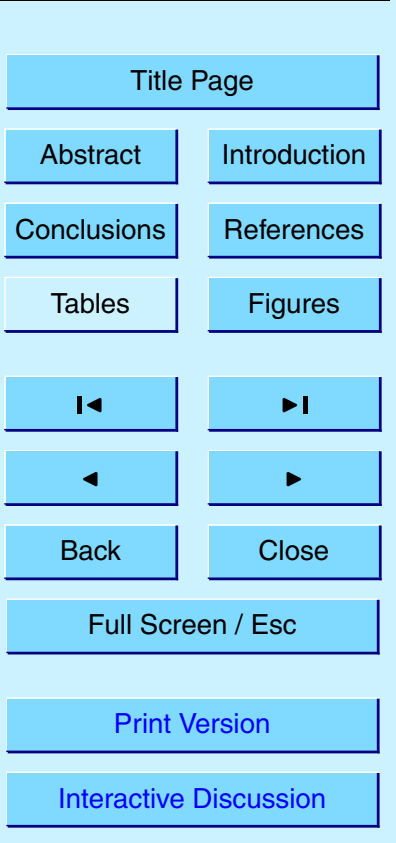

(c) EGU 2003 
tegrated monthly mean $\mathrm{O}_{3}$ column over the $1012-63.3 \mathrm{hPa}$ layer is in agreement with the observed columns. Note that this upper boundary of $63.3 \mathrm{hPa}$ is different from the 20-30 hPa as mentioned in Bhartia et al. (1996) and Ziemke et al. (1998). Fishman et al. $(1999,2003)$ therefore suggests that the "tropospheric" SBUV $\mathrm{O}_{3}$ profile should 5 be corrected using the Logan (1999) climatology. The assumption is that, although the Logan (1999) climatology may not provide the correct $\mathrm{O}_{3}$ concentrations and columns at a given location, the vertical distribution in both space and time are represented reasonably well by the climatology. The climatology can then be used to redistribute the $\mathrm{O}_{3}$ column values in the lowest three SBUV layers while keeping the total SBUV $\mathrm{O}_{3}$ 10 amount of the lowest three layers fixed.

The correction as defined and formulated in Fishman et al. (2003) is as follows (see Fig. 6 in Fishman et al. (2003) and according to ACPD interactive comment 3S386). The retrieval method starts by obtaining the lowest part of twelve $\mathrm{SBUV} \mathrm{O}_{3}$ subcolumns:

Layer 1: Column A (1000-253 hPa)

Layer 2 : $\quad$ Column B (253-126 hPa)

Layer 3 : $\quad$ Column C (126-63 hPa).

Next, the Logan (1999) tropospheric $\mathrm{O}_{3}$ climatology is partitioned into sub-columns that correspond closely to the SBUV sub-layers between 1000 and $100 \mathrm{hPa}$ (the Logan 20 (1999) climatology provides data up to $100 \mathrm{hPa}$ ):

Column X (1000-250 hPa)

Column Y $(250-125 \mathrm{hPa})$

Column Z (125-100 hPa).

Additional information is needed to extend the Logan (1999) climatology up to $63.3 \mathrm{hPa}$ 25

so that it matches with the lowest three SBUV layers (layers A, B, C in Eq. 1).
ACPD

3, 5777-5802, 2003

Problems regarding

the tropospheric $\mathrm{O}_{3}$ residual method

A. T. J. de Laat and

I. Aben

(c) EGU 2003 
Fishman et al. (2003) assume that the sum of the $\mathrm{O}_{3}$ in the three layers from the SBUV measurement is correct (in accordance with the findings of Fishman and Balok, 1999). The approach then followed is that the difference between the SBUV columns $(A+B+C)$ and Logan columns $(X+Y+Z)$ is added to the Logan (1999) climatology to 5 represent the "missing" climatology between $100-63 \mathrm{hPa}$. The "new" column $\mathrm{Z}^{*}$ (125$63 \mathrm{hPa}$ ) is defined by Fishman et al. (2003) as:

$Z^{*}=Z+\Delta Z=Z+(A+B+C)-(X+Y+Z)=(A+B+C)-(X+Y)$.

Next, the ratio of climatological layers $\left(X+Y+Z^{*}\right)$ to the sum of the lowest three SBUV layers $(A+B+C)$ is calculated. This ratio is then used to scale the climatological total $10 \mathrm{O}_{3}$ between $1000-63 \mathrm{hPa}$ to the observed (SBUV) total $\mathrm{O}_{3}$ for these layers. The coefficients $R_{1}, R_{2}, R_{3}$ represent the ratios of the three layers in the extended Logan (1999) climatology and are referred to as the correction ratios of layers 1,2 and 3 .

$R_{1}=X /\left(X+Y+Z^{*}\right)=X /(X+Y+(A+B+C)-(X+Y))=X /(A+B+C)$

$\mathrm{R}_{2}=\mathrm{Y} /\left(\mathrm{X}+\mathrm{Y}+\mathrm{Z}^{*}\right)=\mathrm{Y} /(\mathrm{A}+\mathrm{B}+\mathrm{C})$

$R_{3}=Z^{*} /\left(X+Y+Z^{*}\right)=((A+B+C)-(X+Y)) /(A+B+C)$.

The coefficients $R_{1}, R_{2}$ and $R_{3}$ are then multiplied to provide the new layers $A^{*}, B^{*}$ and $C^{*}$ :

$A^{*}=R_{1} \times(A+B+C)=X$

$B^{*}=R_{2} \times(A+B+C)=Y$

$C^{*}=R_{3} \times(A+B+C)=(A+B+C)-(X+Y)$.

Note that as a result of putting the entire difference between the SBUV total column $(A+B+C)$ and the Logan (1999) climatology $(X+Y+Z)$ in the missing part of the climatology $\Delta Z(=(A+B+C)-(X+Y+Z))$, layers $X$ and $Y$ remain unchanged. Consequently,
ACPD

3, 5777-5802, 2003

Problems regarding the tropospheric $\mathrm{O}_{3}$ residual method

A. T. J. de Laat and

I. Aben

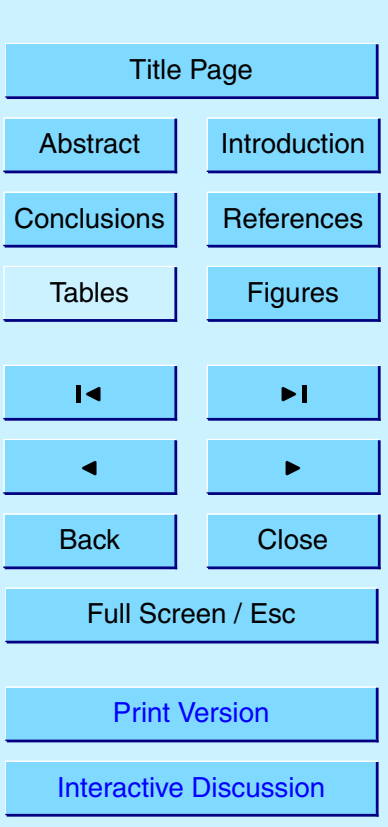

(c) EGU 2003 
the new layers $A^{*}$ and $B^{*}$ are equal to $X$ and $Y$, respectively, which are the quantities in the original Logan (1999) climatology. The SBUV measured $(A+B+C)$ sub-columns are thus not effectively redistributed according to the Logan (1999) climatology, which we believe is what the authors aimed for (in accordance with Fishman and Balok, 1999).

5 The new quantities $A^{*}, B^{*}$ and $C^{*}$ are used to calculate the SBUV stratospheric $\mathrm{O}_{3}$ column (SBUVSOC):

$\mathrm{SBUV}_{\mathrm{SOC}}=\mathrm{SBUV}_{\mathrm{TOC}}-c \mathrm{C}^{*}-b \mathrm{~B}^{*}-\mathrm{A}^{*}$

in which the coefficients $b$ and $c$ denote the fractions of layers $\mathrm{B}^{*}$ and $\mathrm{C}^{*}$ that are located below the tropopause, obtained from NCEP reanalysis data. The tropospheric $\mathrm{O}_{3}$ residual then becomes:

$\mathrm{TOR}=\mathrm{TOMS}_{\mathrm{TOC}}-\mathrm{SBUV}_{\mathrm{SOC}}=\mathrm{TOMS}_{\mathrm{TOC}}-\mathrm{SBUV}_{\mathrm{TOC}}+c \mathrm{C}^{*}+b \mathrm{~B}^{*}+\mathrm{A}^{*}$.

If we now substitute Eq. (5) in Eq. (7) we get:

$\mathrm{TOR}=\mathrm{TOMS}_{\mathrm{TOC}}-\mathrm{SBUV} \mathrm{TOC}+c \mathrm{C}^{*}+b \mathrm{Y}+\mathrm{X}$.

Problems regarding the tropospheric $\mathrm{O}_{3}$ residual method

A. T. J. de Laat and

I. Aben

Equation (8) has some important consequences. First we assume that the tropopause 15 is located below $125 \mathrm{hPa}$ (which is almost always the case outside of the tropics), so that coefficient $c$ becomes zero:

$\mathrm{TOR}=\mathrm{TOMS}_{\mathrm{TOC}}-\mathrm{SBUV}_{\mathrm{TOC}}+b \mathrm{Y}+\mathrm{X}$.

Equation (9a) consists of two parts. The value $b \mathrm{Y}+\mathrm{X}$ is nothing more then the Logan (1999) climatology below the altitude at which the tropopause is located. Superimposed on this climatology are the daily variations in total $\mathrm{O}_{3}$ (TOMS), assuming that TOMS and SBUV measure the same total $\mathrm{O}_{3}$ columns and because SBUV and TOMS measurements have different sampling times (once per five days/daily). If we assume that the differences in total $\mathrm{O}_{3}$ columns occur randomly (see Sect. 6), then the differences in total $\mathrm{O}_{3}$ columns due to the different sampling times would become negligible averaged over a longer period of time (i.e. if the number of samples is large enough).

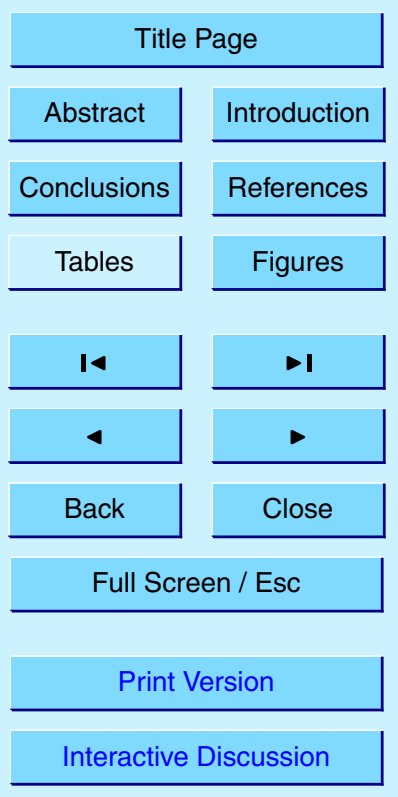

(C) EGU 2003 
As a result, seasonal averages (and probably also monthly averages) primarily reflect changes in the $\mathrm{O}_{3}$ climatology and tropopause heights.

Alternatively, the tropopause can be located between $125 \mathrm{hPa}(15 \mathrm{~km})$ and $63 \mathrm{hPa}$ $(19 \mathrm{~km})$. In that case coefficient $b$ becomes one and if we substitute the expression for $5 \mathrm{C}^{*}$ from Eq. (5) in Eq. (8), we get:

$\mathrm{TOR}=\mathrm{TOMS}_{\mathrm{TOC}}-\mathrm{SBUV}_{\mathrm{TOC}}+c(\mathrm{~A}+\mathrm{B}+\mathrm{C})+(1-c)(\mathrm{X}+\mathrm{Y})$.

Equation (10b) is a linear combination of the SBUV layers A, B and C, the Logan (1999) climatology below $125 \mathrm{hPa}$ and the daily variations in total $\mathrm{O}_{3}$ (TOMS). Note that SBUV column $\mathrm{C}$ includes a part of the stratosphere. The tropopause height in the tropics 10 rarely exceeds $17 \mathrm{~km}(90 \mathrm{hPa})$, so that the value of $(1-c)$ is never small. As a result, also for this case (Eq. 9b) the TOR strongly reflects by the Logan (1999) climatology.

We therefore strongly suspect that, without using any satellite measurements, we should be able to obtain results that in many cases strongly resemble the TOR columns as presented in Fishman et al. (2003), by simply using the Logan (1999) climatology 15 and adding the amount of $\mathrm{O}_{3}$ between $12 \mathrm{hPa}$ and the tropopause height from a different source (such as a climate model).

\section{Total $\mathrm{O}_{3}$ residual from Logan (1999) and tropopause heights}

According to Eqs. (9a) and (9b) the TOR columns in Fishman et al. (2003) are the combination of the Logan (1999) climatology below the tropopause, superimposed with the differences between daily TOMS total $\mathrm{O}_{3}$ columns and once-per-5-days SBUV total $\mathrm{O}_{3}$ columns. If differences between SBUV and TOMS total $\mathrm{O}_{3}$ columns for a 5-day period occur randomly, it is reasonable to assume that these differences are small when averaged over longer periods of time (see Sect. 6). Thus, the TOR product for seasonal averages mainly reflects the Logan (1999) climatology below the tropopause and only marginally reflects tropospheric $\mathrm{O}_{3}$ as measured by TOMS/SBUV. To further substantiate this point we calculated the TOR using the Logan (1999) climatology and

ACPD

3, 5777-5802, 2003

Problems regarding the tropospheric $\mathrm{O}_{3}$ residual method

A. T. J. de Laat and

I. Aben

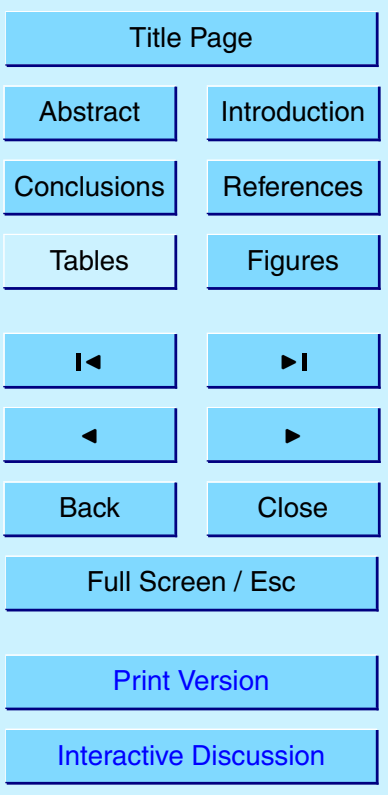

(C) EGU 2003 
the tropopause heights from an ECHAM model simulation on T63 $\left(\sim 2^{\circ} \times 2^{\circ}\right.$ resolution). $\mathrm{O}_{3}$ concentrations above $100 \mathrm{hPa}$ were assumed equal to the $\mathrm{O}_{3}$ concentrations in the Logan (1999) climatology at $100 \mathrm{hPa}$. The 19-layer ECHAM model (Roeckner, 1996) simulation was done using the so-called "nudging" procedure (assimilating ECMWF 5 analysis data) for the year 1996 (Jeuken et al., 1996). The ECHAM model has a vertical coordinate system that follows the surface elevation. The 19-layer ECHAM model has typically a vertical resolution of about $1-2 \mathrm{~km}$ in the tropopause region. The tropopause height was defined as the height (vertical gridpoint) for which the vertical temperature gradient was $-3^{\circ} \mathrm{K} / \mathrm{km}$.

10 Fig. 1 shows the TOR columns from this methodology for the four seasons. The TOR columns show very similar spatial and seasonal variations as the 1979-2000 climatology in Fishman et al. (2003). Differences could be explained by a number of factors: (1) we only used the tropopause height for one year (1996), (2) we used a different tropopause height definition, (3) we did not take into account the fraction of the SBUV 15 column that is added for tropopause heights above $100 \mathrm{hPa}$ as is applied in Fishman et al. (2003), (4) the horizontal resolution of TOMS is about $1^{\circ} \times 1.25^{\circ}$ compared to the $2^{\circ} \times 2^{\circ}$ resolution from the ECHAM model so that more surface elevation details should be visible in the Fishman et al. (2003) TOR than in our TOR and (5) no systematic differences between daily TOMS and once-per-5-days SBUV total $\mathrm{O}_{3}$ column measurements are included. However, it is not the scope of this paper to fully reproduce the Fishman et al. (2003) climatology. We merely want to show that the Logan (1999) climatology with some tropopause height estimation results in a TOR column very similar to that in Fishman et al. (2003), as we predicted through inspection of Eqs. (9a) and (9b). Only very little new information about $\mathrm{O}_{3}$ would be obtained by including the satellite measurements in Fishman's TOR methodology. Fishman et al. (2003) claim that there is a considerable amount of additional information from the satellite measurements in their TOR, and have substantiated this by comparing the TOR climatology for July with the Logan (1999) climatology total $\mathrm{O}_{3}$ columns below $250 \mathrm{hPa}$. However, because the TOR is very dependent on the tropopause height and surface elevation,

\section{Problems regarding the tropospheric $\mathrm{O}_{3}$ residual method}

A. T. J. de Laat and

I. Aben

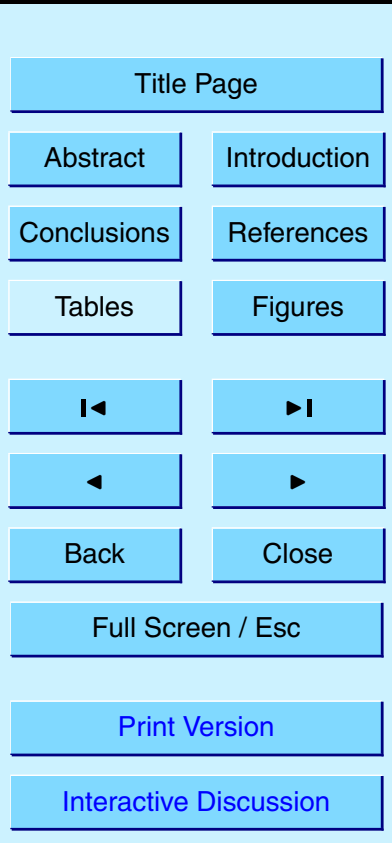


comparing the Logan (1999) climatology below $250 \mathrm{hPa}$ (and without taking surface elevation into account) with TOR does not prove that the differences are caused by the satellite measurements. If one takes the surface elevation and tropopause heights into account, which is what we have done in this section, the resulting TOR are very similar 5 to the TOR in Fishman et al. (2003).

\section{Interpretation of Asian "summer pollution events"}

According to Fishman et al. (2003) and Pierce et al. (2003) the TOR columns show enhanced values during June-August over southern and eastern Asia. Furthermore, enhanced TOR values are seen over the Ganges valley in northern India. It is claimed that this is widespread pollution caused by emissions over northern India. However, when looking in detail at the 1979-2000 TOR climatology in Fishman et al. (2003), we see that this is a persistent feature throughout all seasons. Furthermore, this feature is also present in the "Logan/ECHAM tropopause" TOR in Figs. 1 and 2. There is no such a feature in the actual Logan (1999) $\mathrm{O}_{3}$ surface concentrations, rather the $\mathrm{O}_{3}$ concen15 trations increase along the latitude over India without any longitudinal variations. We therefore conclude that this feature is not caused by pollution, but relates to other processes: a geographical effect and seasonal changes in the TOR values. As noted, the total $\mathrm{O}_{3}$ column values in the Logan (1999) climatology increase with latitude over southern Asia, but without longitudinal variation. However, there is also a large surface

elevation difference between northern India (close to sea level) and the Tibetan plateau (approximately $3-5 \mathrm{~km}$ altitude). Therefore, combining the surface elevation changes with the northward increasing $\mathrm{O}_{3}$ concentrations results in TOR variations that follow local elevation changes. Separate from the influence of the surface elevation however is the question why the TOR column changes so much between the seasons. The $\mathrm{O}_{3}$ concentrations over southern Asia in the Logan (1999) climatology do not change enough to explain the large differences between summer and winter TOR over India and China. However, large differences between summer and winter TOR are also

\section{Problems regarding the tropospheric $\mathrm{O}_{3}$ residual method}

A. T. J. de Laat and

I. Aben

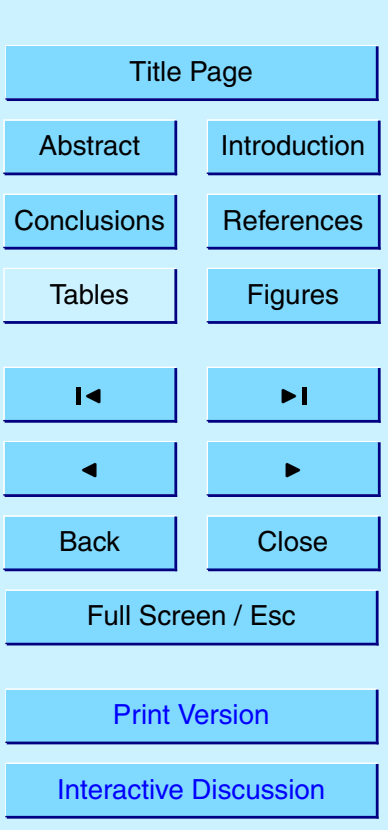

(C) EGU 2003 
present in the "Logan/ECHAM tropopause" climatology (Figs. 1, 2). The explanation we find by looking at the differences in tropopause height between the winter and summer season (Fig. 3). There is a large change in tropopause height as large as $5 \mathrm{~km}$ between winter and summer for this region. This explains the large difference between 5 summer and winter TOR columns over southern Asia: during summer the tropospheric $\mathrm{O}_{3}$ column is simply about one-third larger than during winter. Moreover, the highest $\mathrm{O}_{3}$ concentrations are found close to the tropopause, so that a considerable amount of $\mathrm{O}_{3}$ is added to the tropospheric $\mathrm{O}_{3}$ column when the tropopause is higher.

We investigate how much $\mathrm{O}_{3}$ would be needed to explain these TOR differences be10 tween summer and winter (differences are 15-25 DU, both in the Fishman et al. (2003) climatology as well as in the "Logan/ECHAM tropopause" TOR). We can convert Dobson Units to mixing ratios as follows:

$\mathrm{O}_{3}=\mathrm{F}_{\mathrm{DU}} \times g \times \mathrm{M}_{\text {air }} \times\left(\Delta_{\mathrm{DU}}\right) /(0.1 \times d p \times a v o)$.

In which $F_{D U}$ is the conversion factor from molecules/cm2 to Dobson Units $15 \quad\left(2.69 \cdot 10^{16}\right.$ molecules $\left./ \mathrm{cm}^{2}\right), g$ is the gravity constant $\left(9.81 \mathrm{~m} / \mathrm{s}^{2}\right), \mathrm{M}_{\text {air }}$ is the molar mass of air $(28.64 \mathrm{gr} / \mathrm{mol}), \Delta_{\mathrm{DU}}$ is the difference in $\mathrm{O}_{3}$ column thickness, $d p$ is the layer thickness in $\mathrm{Pa}$, avo is the Avogadro constant $\left(6.0210^{23} \mathrm{~mol}^{-1}\right)$ and 0.1 is a factor for the conversion from $\mathrm{m}^{2}$ to $\mathrm{cm}^{2}$ and $\mathrm{kg}$ to gr. If we assume that a 15DU change occurs in the atmospheric boundary layer, and substitute a layer thickness of $150 \mathrm{hPa}$ (1000-850 hPa which is roughly a thickness of $1.5 \mathrm{~km}$ ) into Eq. (10), the difference in $\mathrm{O}_{3}$ concentrations is approximately $125 \mathrm{ppbv}$ (mixing ratio of $1.25 \cdot 10^{-7}$ ). If a typical $\mathrm{O}_{3}$ concentration during winter in northern India would be about 50 ppbv (Logan, 1999), then during summer it would be $175 \mathrm{ppbv}$, which is a very unrealistic $\mathrm{O}_{3}$ concentration at the surface, even for strong pollution events. On the other hand, a layer of $150 \mathrm{hPa}$ in the tropopause region is similar to a change from 10 to $15 \mathrm{~km}$ altitude, which is roughly the tropopause height change from the ECHAM model for this region, and a concentration of $125 \mathrm{ppbv}$ for the tropopause region is very reasonable. The $\mathrm{O}_{3}$ enhancements during local summer over India and China are not related to pollution, but primarily the
ACPD

3, 5777-5802, 2003

Problems regarding the tropospheric $\mathrm{O}_{3}$ residual method

A. T. J. de Laat and

I. Aben

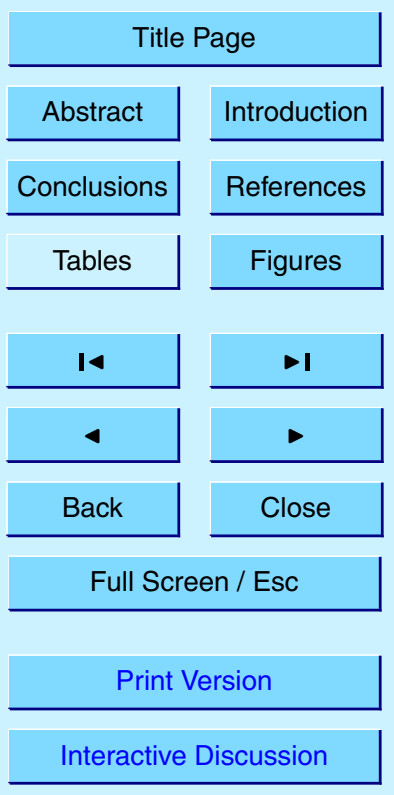

(C) EGU 2003 
result of changes in tropopause heights. A summertime maximum in surface $\mathrm{O}_{3}$ concentrations is not in agreement with our current knowledge, which as also noted by Kim in the ACPD interactive comment 3-S470. Furthermore, this summertime maximum is also not present in the Logan (1999) climatology.

\section{5. Suggestion for improving the TOMS-SBUV TOR column}

According to Fishman and Balok (1999), the SBUV total $\mathrm{O}_{3}$ column amount between 1000 and $63 \mathrm{hPa}$ is approximately correct while the distribution of $\mathrm{O}_{3}$ amongst the SBUV three lowest layers is not good. In our view the aim of the TOR methodology is to redistribute the $1000-63 \mathrm{hPa}$ column according to the Logan (1999) climatological 10 vertical $\mathrm{O}_{3}$ distribution. However, the Logan (1999) climatology does not go beyond $100 \mathrm{hPa}$, whereas the three lowest SBUV layers range from 1000 to $63 \mathrm{hPa}$. Clearly, some extension of the Logan (1999) climatology is needed to $63 \mathrm{hPa}$ in order to sensibly redistribute the $\mathrm{O}_{3}$ amongst the three lowest SBUV layers. As indicated in Sect. 2, Fishman et al. (2003) choose to extend the Logan (1999) climatology vertically above $15100 \mathrm{hPa}$ by adding the difference between the Logan (1999) climatology total $\mathrm{O}_{3}$ column and the total of the SBUV three lowest layers to the region above $100 \mathrm{hPa}$. By doing so, the lower two layers $\left(A^{*}\right.$ and $\left.B^{*} ; 1000-125 \mathrm{hPa}\right)$ are effectively identical to the Logan (1999) climatology values and are not scaled to the SBUV $1000-63 \mathrm{hPa}$ measured column. We believe that this violates the idea of using the Logan (1999) climatology to sensibly redistribute the measured $A, B$ and $C$ columns.

As indicated in Sect. 2, the "problems" arise from the assumption to extend the Logan (1999) climatology vertically above $100 \mathrm{hPa}$ by using SBUV data (Eq. 3). There appears to be no justification for why the $\mathrm{O}_{3}$ climatology above $100 \mathrm{hPa}$ should be corrected the way it is being done (using the total of the SBUV levels 1-3 minus the Logan climatology above $100 \mathrm{hPa}$ by assuming the same concentration of $\mathrm{O}_{3}$ above $100 \mathrm{hPa}$

ACPD

3, 5777-5802, 2003

Problems regarding the tropospheric $\mathrm{O}_{3}$ residual method

A. T. J. de Laat and

I. Aben

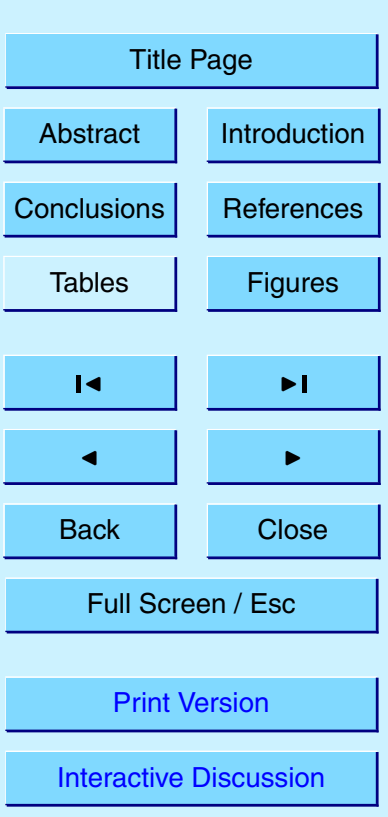

(C) EGU 2003 
as in the highest Logan (1999) climatology layer. Equation (3) then becomes:

With a numerical value for $a$, which is the thickness of the layer between 100 and $63 \mathrm{hPa}$ relative to the thickness of the layer between 125 and $100 \mathrm{hPa}$ (which yields a 5 value for $a$ of about 1.5). Using Eq. (11), we then get for the subcolumns $A^{*}, B^{*}, C^{*}$ :

$A^{*}=X \times(A+B+C) /\left(X+Y+Z^{*}\right)$

$B^{*}=Y \times(A+B+C) /\left(X+Y+Z^{*}\right)$

$\mathrm{C}^{*}=\mathrm{Z}^{*} \times(\mathrm{A}+\mathrm{B}+\mathrm{C}) /\left(\mathrm{X}+\mathrm{Y}+\mathrm{Z}^{*}\right)$

\section{Problems regarding the tropospheric $\mathrm{O}_{3}$ residual method}

A. T. J. de Laat and

I. Aben

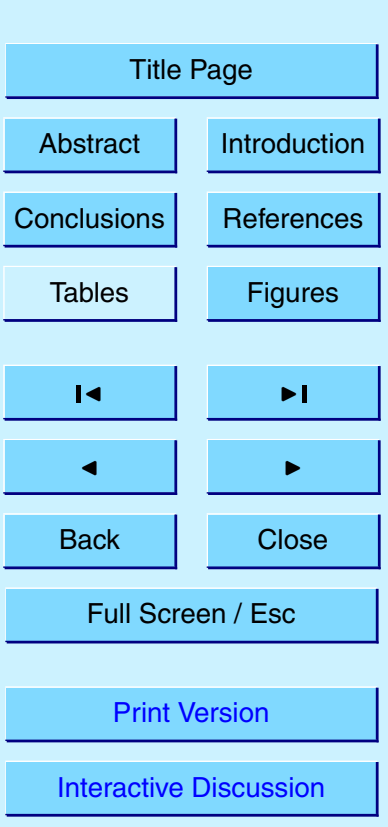

(C) EGU 2003 
at maximum, and preferably smaller. To investigate this hypothesis we first examine the total $\mathrm{O}_{3}$ column over Samoa as measured by the TOMS satellite. Samoa is considered a clean Pacific equatorial location where tropospheric $\mathrm{O}_{3}$ concentrations are generally very low throughout the troposphere, as it is remote from any major pollution source.

5 Furthermore, changes in the tropical tropopause height are generally small (see also Fig. 3). As a result, the tropospheric $\mathrm{O}_{3}$ column is low ( $<15 \mathrm{DU}$ according to Fishman et al., 2003), and variations between the seasons are small.

Figure $4 a$ shows the total $\mathrm{O}_{3}$ column over Samoa measured by TOMS (version 7). The seasonal cycle can easily be discerned, with higher column densities towards the 10 end of the year. However, superimposed on the seasonal cycle is a highly varying signal. Figure $4 \mathrm{~b}$ shows the 5 -day standard deviation values of the total $\mathrm{O}_{3}$ column for Samoa. Again, there is a seasonal cycle, with a higher variability during the season when the overall concentrations are higher. On average, the 5-day standard deviation of the total $\mathrm{O}_{3}$ column is about $5 \mathrm{DU}$ (similar to results from Ziemke et al. (1998), who, based on Microwave Limb Sounder stratospheric $\mathrm{O}_{3}$ profile measurements, derived a typical $2 \sigma$ variation of the tropical stratospheric $\mathrm{O}_{3}$ column of $10 \mathrm{DU}$ ). However, this value varies between 1 and $15 \mathrm{DU}$, and thus can be as high as the total tropospheric $\mathrm{O}_{3}$ column at Samoa. Since the variability of tropospheric total $\mathrm{O}_{3}$ column is small for this remote site, the high variability of the total $\mathrm{O}_{3}$ column densities must be caused by variations in the stratospheric $\mathrm{O}_{3}$ column densities.

A similar picture occurs when we investigate the total $\mathrm{O}_{3}$ column variability at Lauder (New Zealand). Lauder is a mid-latitude station, so that the seasonal cycle of the total $\mathrm{O}_{3}$ column is much larger than that at Samoa. According to Fig. $5 \mathrm{a}$, the total $\mathrm{O}_{3}$ column densities at Lauder range from about 250 to $400 \mathrm{DU}$. The 5-day standard variation of the total $\mathrm{O}_{3}$ column (Fig. $5 \mathrm{~b}$ ) is on average approximately $20 \mathrm{DU}$, with a range from 5 to $50 \mathrm{DU}$.

To further investigate the $\mathrm{O}_{3}$ column variability we looked at stratospheric $\mathrm{O}_{3}$ profiles obtained from lidar measurements at the site (Brinksma et al., 2002). There are typically about 100 profiles per year (about one every 3 days). Because of the large

\section{Problems regarding the tropospheric $\mathrm{O}_{3}$ residual method}

A. T. J. de Laat and

I. Aben

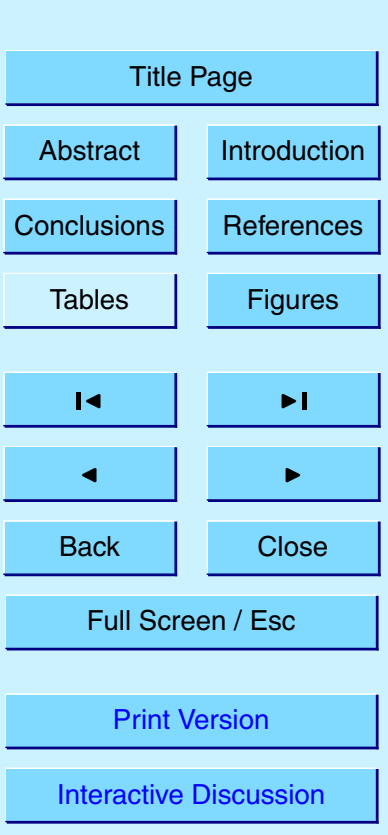

(C) EGU 2003 
amount of $\mathrm{O}_{3}$ profiles, we can compare the variability of the lidar profiles with the variability of the TOMS total $\mathrm{O}_{3}$ column measurements. We took one year (1997) of data to investigate the variability. Figure 6 shows the stratospheric $\mathrm{O}_{3}$ column variations for different layers (11-45, 15-45 and 19-45 km altitude layers) and the corresponding 5 TOMS measurements. The $\mathrm{O}_{3}$ column of above $45 \mathrm{~km}$ altitude is typically only $2 \mathrm{DU}$, and variations are small. We can assume that $\mathrm{O}_{3}$ above $45 \mathrm{~km}$ adds little to the total $\mathrm{O}_{3}$ column variability. The standard deviation of the TOMS measurements for this period is 32.4 DU for TOMS collocations with lidar measurements (31.6 DU for all TOMS measurements). The standard deviation for the lidar measurements are 26.4, 22.7 10 and $15.5 \mathrm{DU}$ for $\mathrm{O}_{3}$ columns between $11-45,15-45$ and $19-45 \mathrm{~km}$, respectively. The variability of the $\mathrm{O}_{3}$ column increases with decreasing altitude. This should not be a surprise considering that the upper-troposphere/lower stratosphere region is a much more dynamically active region than the middle and upper stratosphere. Lauder is a mid-latitude site, so that the tropopause generally will be below $15 \mathrm{~km}$ altitude, and dur15 ing winter closer to $10 \mathrm{~km}$ altitude. About $2 / 3$ of the total $\mathrm{O}_{3}$ column variability occurs above $15 \mathrm{~km}$ altitude and can be considered stratospheric. What is more, the value of the standard deviation above $15 \mathrm{~km}$ altitude was $22.7 \mathrm{DU}$, which means that variations in the stratospheric $\mathrm{O}_{3}$ column can be as high as 45DU (2 times the standard deviation). This value is in agreement with the 5-day standard deviations, which, on occasion, could be as high as $50 \mathrm{DU}$. From this analysis we conclude that a constant stratospheric $\mathrm{O}_{3}$ column densities for a 5-day period is not a reasonable assumption.

At the same time it must be mentioned that daily stratospheric $\mathrm{O}_{3}$ column variations appear to occur randomly. In the TOR method of Fishman et al. (2003) the onceper-5-days SBUV total $\mathrm{O}_{3}$ column measurements are subtracted from the every day total $\mathrm{O}_{3}$ column measurements from TOMS. Over longer periods of time a random signal will average out, and it is likely that this is also the case for the TOMS minus SBUV total $\mathrm{O}_{3}$ column densities. To estimate this effect we calculated the differences between the daily TOMS total $\mathrm{O}_{3}$ column measurements and the corresponding 5-day TOMS total $\mathrm{O}_{3}$ columns (from -2 days to +2 days; for the period 1996-2003). The

\section{Problems regarding the tropospheric $\mathrm{O}_{3}$ residual method}

A. T. J. de Laat and

I. Aben

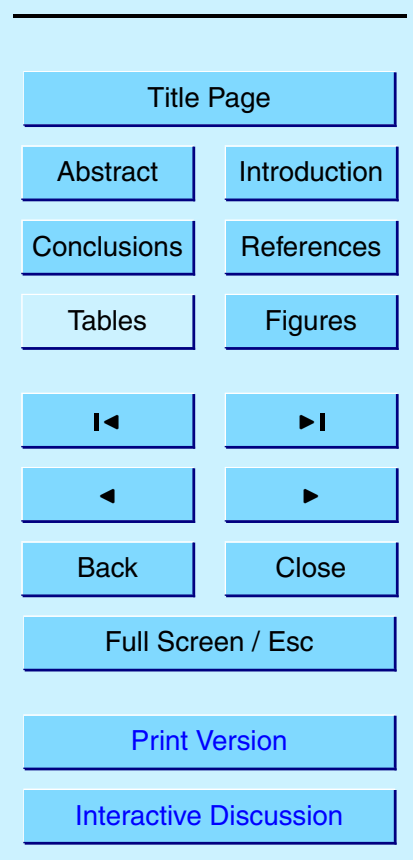

(C) EGU 2003 
average absolute difference for a 5-day period was 15.1 DU for Lauder and 4.0 DU for Samoa. For one month the values were 5.7 and 1.5 DU, and for three months the differences were 3.2 and 0.6 DU for Lauder and Samoa, respectively. As expected, the differences ("errors") become less important when averaging over longer periods 5 of time. However, for a single month the 5-day sampling of stratospheric $\mathrm{O}_{3}$ columns introduces on average an error in the TOR of about 10-20\% for Lauder and Samoa. Although these are only rough estimates of the error introduced by the 5-day sampling, they indicate that one should be careful when for example looking at specific single months. Furthermore, these examples show that further investigation is needed to 10 assess the error due to stratospheric $\mathrm{O}_{3}$ variability.

\section{Summary and discussion}

In this article we have shown that the method used to retrieve TOR columns as described in Fishman et al. (2003) and applied in Pierce et al. (2003) yields a TOR that can be considered as the $\mathrm{O}_{3}$ climatology from Logan (1999) below the tropopause, 15 superimposed with differences between every-day TOMS and once-per-5 days SBUV total $\mathrm{O}_{3}$ column measurements. The TOR product therefore is strongly biased to the effect of tropopause height variations and only marginally relies on the used satellite data. We have shown that, by simply applying a realistic tropopause height estimation to the Logan (1999) climatology we can derive a "TOR" that is very similar to the 20 TOR climatology presented by Fishman et al. (2003). As a result, we think that the interpretation given to TOR in the application presented in Fishman et al. (2003) is not correct. We have shown that the high TOR columns during summer over India and China are not the result of pollution but of a large increase in tropopause heights in this region. We believe that the formulation of the method as presented in Fishman et al. (2003) is probably not the method they had in mind. We have therefore made a possible suggestion to improve the TOR method using the basic assumptions as presented by the authors in an earlier publication (Fishman and Balok, 1999). However,
ACPD

3, 5777-5802, 2003

Problems regarding the tropospheric $\mathrm{O}_{3}$ residual method

A. T. J. de Laat and

I. Aben

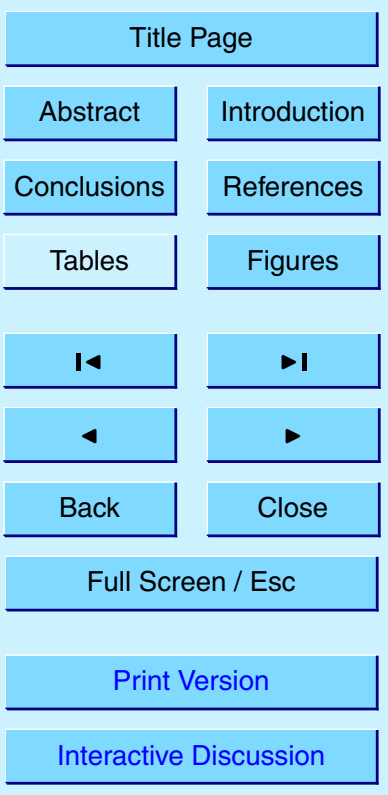

(C) EGU 2003 
we have also shown that the implicit assumption that the total stratospheric $\mathrm{O}_{3}$ column is nearly constant over 5 days is not valid. This could pose another complication in this TOR methodology. On the other hand, the 5-day variability of the stratospheric $\mathrm{O}_{3}$ column may occur randomly. It is possible that the error introduced by this assumption 5 will average out when TOR columns are averaged over longer periods of time (monthsseasons). Investigating TOMS total $\mathrm{O}_{3}$ columns for Samoa and Lauder confirms that this effect becomes smaller when averaging over longer periods of time. At the same time, however, it shows that the errors are not that small that they can be ignored. We therefore conclude that the effect of stratospheric $\mathrm{O}_{3}$ variability in combination with 10 5-day SBUV sampling on the final TOR column should be investigated in more detail.

Even though the method applied by Fishman et al. (2003) to retrieve TOR columns from satellite measurements is incorrect, the results of the retrieval do not appear to be unreasonable. As was shown, the Fishman TOR column is largely dependent on the Logan (1999) climatology. This climatology itself is based on a large number of $\mathrm{O}_{3}$ sonde measurements. Therefore, the climatology is not an unreasonable approximation of the actual $\mathrm{O}_{3}$ concentrations. And averaged over longer periods of time, the actual $\mathrm{O}_{3}$ concentrations will not differ too much from the climatology. Furthermore, by scaling the Logan (1999) climatology to the actual tropopause height, the TOR column will also correlate well with synoptical systems and with seasonal variations in 20 parameters since the tropopause height also changes with season. As a result, the TOR column variations appear to be very realistic. But it should be realized that for this satellite data is not needed.

In this paper we present an alternative to extend the Logan (1999) climatology to $63 \mathrm{hPa}$ and to redistribute the $\mathrm{O}_{3}$ in the three lowest SBUV layers. Further study is needed to optimize the Logan (1999) climatology extension. If the TOR product is being improved along the suggested changes, and it can be shown that the stratospheric variability does not introduce large errors in the TOR columns, the TOR columns could become a valuable dataset. However, until these changes have been applied, and a better validation of the dataset against independent measurements has been per-
ACPD

3, 5777-5802, 2003

Problems regarding the tropospheric $\mathrm{O}_{3}$ residual method

A. T. J. de Laat and

I. Aben

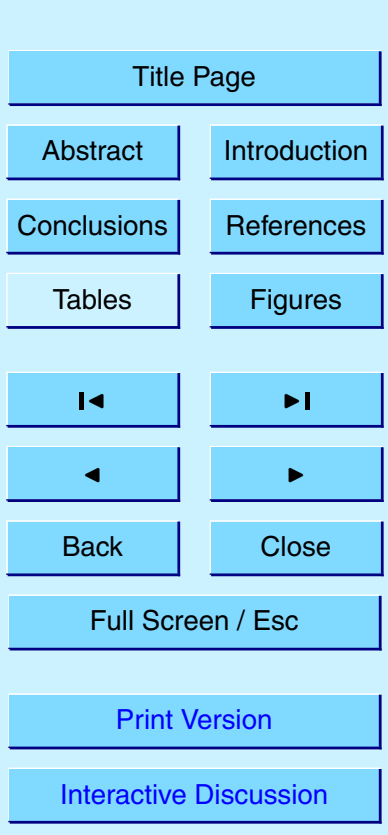

(C) EGU 2003 
formed, there is little new added information in the current dataset.

Moreover, one should be careful with interpretation of tropospheric $\mathrm{O}_{3}$ columns. As was shown for India and China, the tropospheric $\mathrm{O}_{3}$ columns are strongly dependent on tropopause height variations. The effects of tropopause height changes on total 5 tropospheric columns obscures the observation of pollution, therefore the interpretation of tropospheric columns should always be accompanied by a description of the tropopause height changes, especially outside the tropics. Without this knowledge, it is not possible to fully understand the tropospheric $\mathrm{O}_{3}$ column variability, which in turn can lead to wrong conclusions about the temporal and spatial variability of tropospheric ${ }_{10} \mathrm{O}_{3}$.

Acknowledgements. The authors would like to acknowledge and thank the following groups and/or people for making datasets publicly available: NASA and the TOMS science team (TOMS total $\mathrm{O}_{3}$ column data); J. Logan, for the $\mathrm{O}_{3}$ climatology (currently at Harvard University); D. Swart (RIVM, the Netherlands) and the Network for the Detection of Stratospheric Change (NDSC; http://www.ndsc.ncep.noaa.gov) for the lidar measurements at Lauder. The authors would specifically like to thank D. Swart and A. Maurellis (SRON) for their comments on the paper.

Part of the contents of this paper is based on ACPD discussions with regard to the Fishman et al. (2003) paper (Atmos. Chem. Phys. Discuss., 3, 1453-1476, 2003; SC S355; AC S386; SC S407; AC S861).

\section{References}

Bhartia, P. K., McPeters, R. D., Mateer, C. L., Flynn, L. E., and Wellemeyer, C.: Algorithm for the estimation of vertical ozone profiles from the backscattered ultraviolet technique, J. Geophys. Res., 101, 18793-18 806, 1996.

Brinksma, E. J., Ajtic, J., Bergwerff, J. B., Bodeker, G. E., Boyd, I. S., de Haan, J. F., Hogervorst, W., Hovenier, J. W., and Swart, D. P. J.: Five years of observations of ozone profiles over Lauder, New Zealand, J. Geophys. Res., 107, 10.1029/2001JD000737, 2002.

Problems regarding the tropospheric $\mathrm{O}_{3}$ residual method

A. T. J. de Laat and

I. Aben

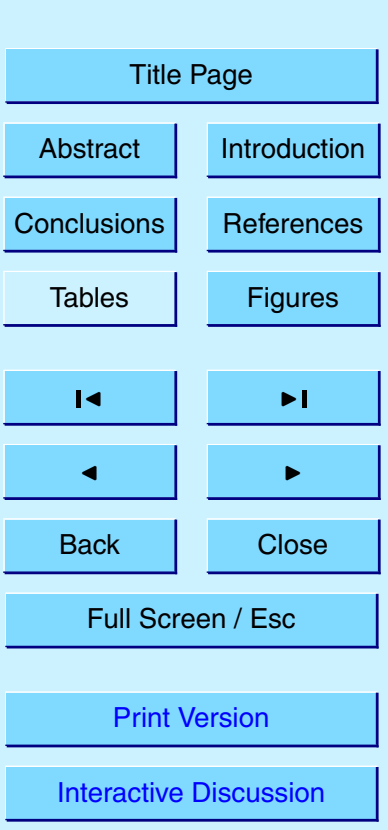


Cuevas, E., Gil, M., Rodriguez, J., Navarro, M., and Hoinka, K. P.: Sea-land total ozone differences from TOMS: GHOST effect, J. Geophys. Res., 106, 27 745-27 755, 2001.

Fishman, J., Brackett, V. G., Browell, E. V., and Grant, W. B., Tropospheric ozone derived from TOMS/SBUV measurements during TRACE A, J. Geophys. Res., 101, 24 069-24 082, 1996.

5 Fishman, J. and Balok, A. E.: Calculation of daily tropospheric ozone residuals using TOMS and empirically improved SBUV measurements: Application to an ozone pollution episode over the eastern United States, J. Geophys. Res., 104, 30 319-30 340, 1999.

Fishman, J., Wozniak, A. E., and Creilson, J. K.: Global distribution of tropospheric ozone from satellite measurements using the empirically corrected tropospheric ozone residual technique: identification of the regional aspects of air pollution, Atmos. Chem. Phys., 3, 1453-1476, 2003.

Hasekamp, O. P. and Landgraf, J.: Tropospheric ozone information from satellite-based polarization measurements, J. Geophys. Res., 107, 10.1029/2001JD001346, 2002.

Hudson, R. D. and Thompson, A. M.: Tropical tropospheric ozone from total ozone mapping 15 spectrometer by a modified residual method, J. Geophys. Res., 103, 22 129-22 145, 1998.

Kim, J. H., Hudson, R. D., and Thompson, A. M.: A new method of deriving time-averaged tropospheric column ozone over the tropics using total ozone mapping spectrometer (TOMS) radiances: Intercomparison and analysis using TRACE A data, J. Geophys. Res., 103, $24317-$ 24 330, 1998.

20 Logan, J. A.: An analysis of ozonesonde data for the troposphere: recommendations for testing 3-D models and development of a gridded climatology for tropospheric ozone, J. Geophys. Res., 104, 16 115-16 149, ftp://ftp.as.harvard.edu/pub/sonde/clim/, 1999.

Newchurch, M. J., Sun, D., Kim, J. H., and Liu, X.: Tropical tropospheric ozone derived using Clear-Cloudy Pairs (CCP) of TOMS measurements, Atmos. Chem. Phys., 3, 683-695, 2003.

Pierce, R. B., Al-Saadi, J. A., Schaack, T., Lenzen, A., Zapotocny, T., Johnson, D., Kittaka, C., Buker, M., Hitchman, M. H., Tripoli, G., Fairlie, T. D., Olson, J. R., Natarajan, M., Crawford, J., Fishman, J., Avery, M., Browell, E. V., Creilson, J., Kondo, Y., and Sandholm, S. T.: Regional Air Quality Modeling System (RAQMS) Predictions of the tropospheric ozone budget over east Asia, J. Geophys. Res., in press, 2003.

so Roeckner, E., Arpe, K., Bengtsson, L., Christoph, M., Claussen, M., Dümenil, L., Esch, M., Giorgetta, M., Schlese, U., and Schulzweida, U.: The atmospheric general circulation model ECHAM-4: Model description and simulation of present-day climate, Rep. 218, Max-PlanckInstitute for Meteorology, Hamburg, Germany, 1996.

ACPD

3, 5777-5802, 2003

Problems regarding the tropospheric $\mathrm{O}_{3}$ residual method

A. T. J. de Laat and

I. Aben

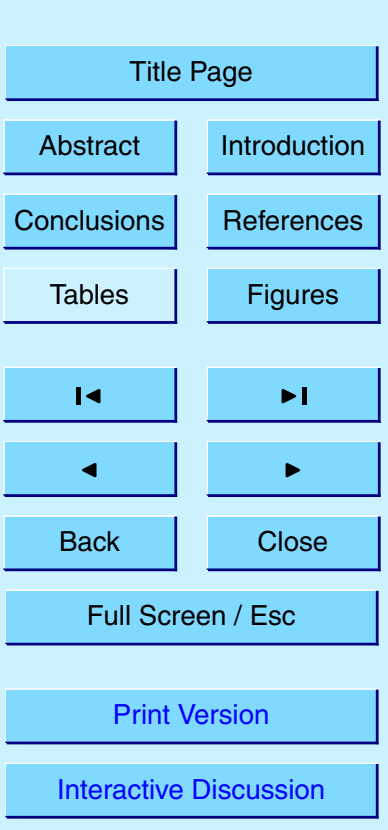

(c) EGU 2003 
SBUV 2003: http://orbit-net.nesdis.noaa.gov/crad/sit/ozone/.

TOMS 2003: http://toms.gsfc.nasa.gov/.

ACPD

Ziemke, J. R., Chandra, S., and Bhartia, P. K.: Two new methods for deriving Tropospheric column ozone from TOMS measurements: assimilated UARS MLS/HALOE and convectivecloud differential techniques, J. Geophys. Res., 103, 22 115-22 128, 1998.

3, 5777-5802, 2003

\section{Problems regarding the tropospheric $\mathrm{O}_{3}$ residual method}

A. T. J. de Laat and

I. Aben

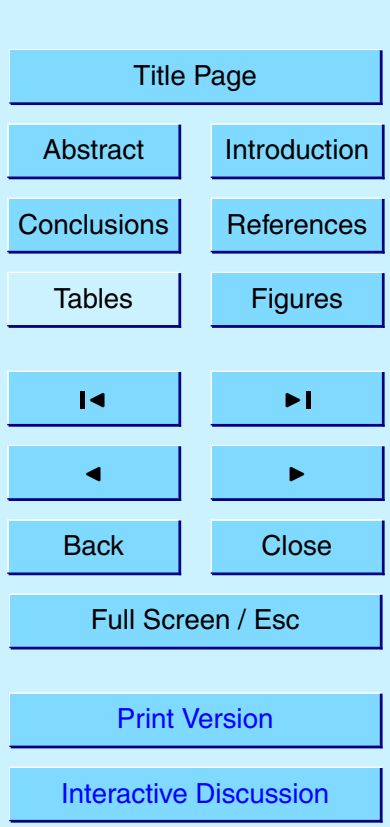



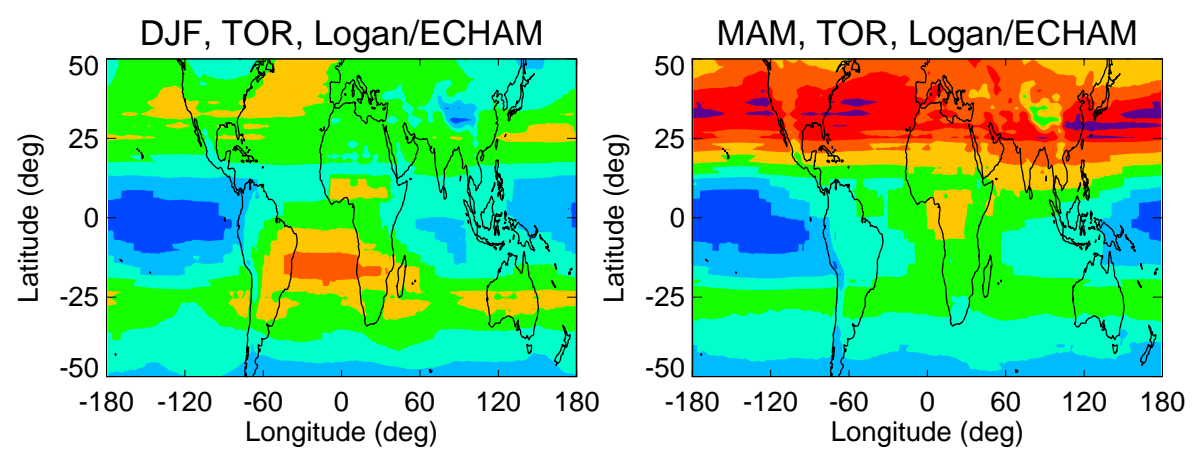

ACPD
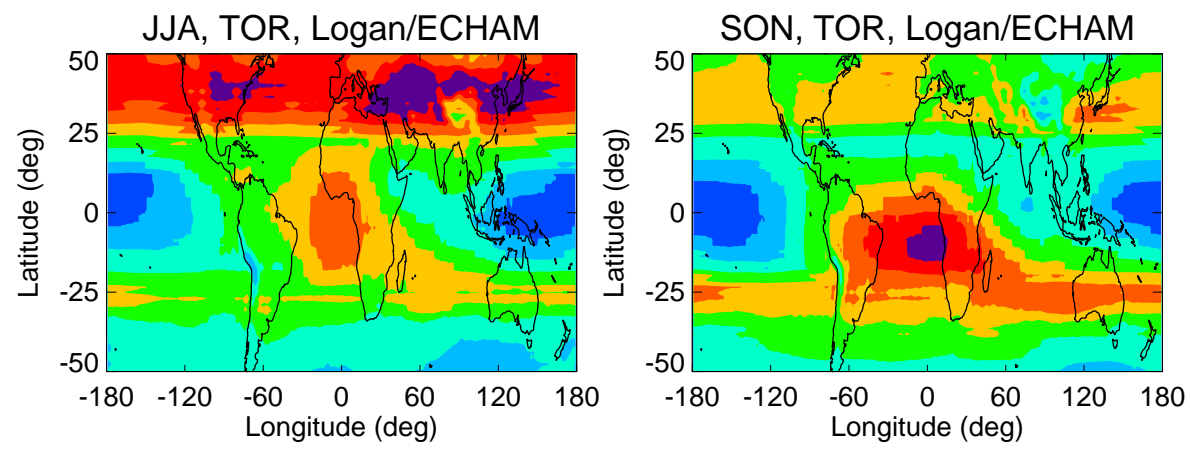

3, 5777-5802, 2003

Problems regarding the tropospheric $\mathrm{O}_{3}$ residual method

A. T. J. de Laat and

I. Aben

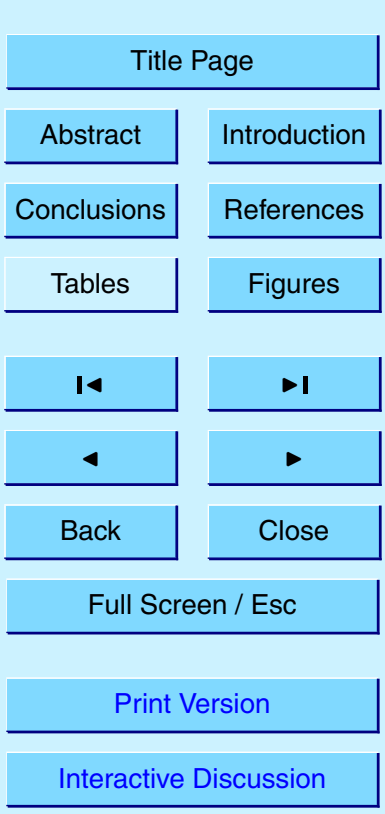

(c) EGU 2003

Fig. 1. Mean seasonal total tropospheric $\mathrm{O}_{3}$ columns (Dobson Units: $1 \mathrm{DU}=$ 2.69.1 $10^{16}$ molecules $\mathrm{cm}^{-2}$ ) using the Logan (1999) climatology and ECHAM tropopause height and surface elevation (DJF: December-January-February, MAM: March-April-May: JJA: JuneJuly-August, SON: September-October-November). ECHAM horizontal resolution is approximately $1.9^{\circ} \times 1.9^{\circ}(\mathrm{T} 63)$. Model simulation was done for 1996 . 


\section{ACPD}

3, 5777-5802, 2003
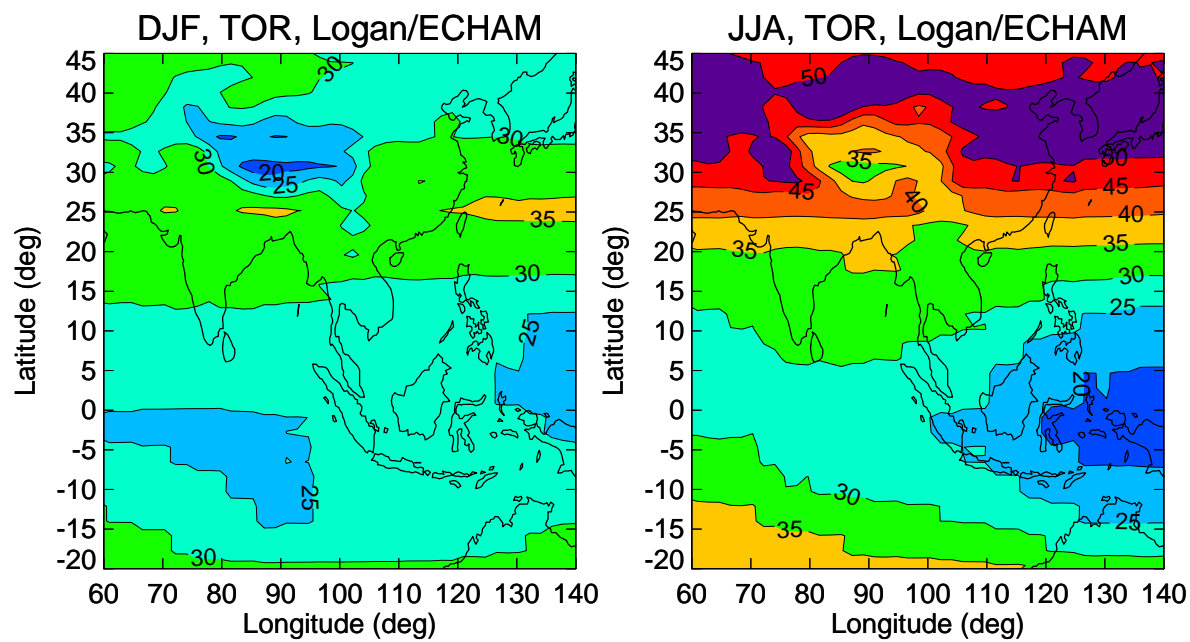

Problems regarding the tropospheric $\mathrm{O}_{3}$ residual method

\section{A. T. J. de Laat and} I. Aben

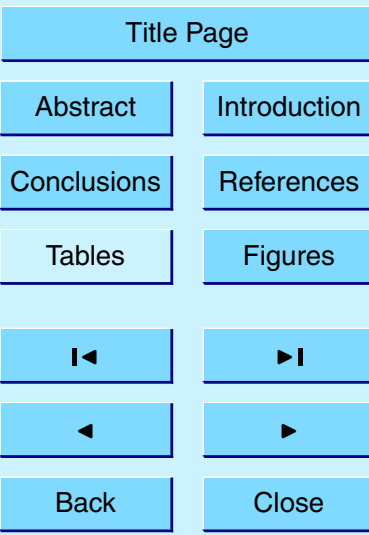

Fig. 2. As Fig. 1 but for southeast Asia for the DJF and JJA seasons.

Full Screen / Esc

Print Version

Interactive Discussion

(C) EGU 2003 


\section{ACPD}

3, 5777-5802, 2003

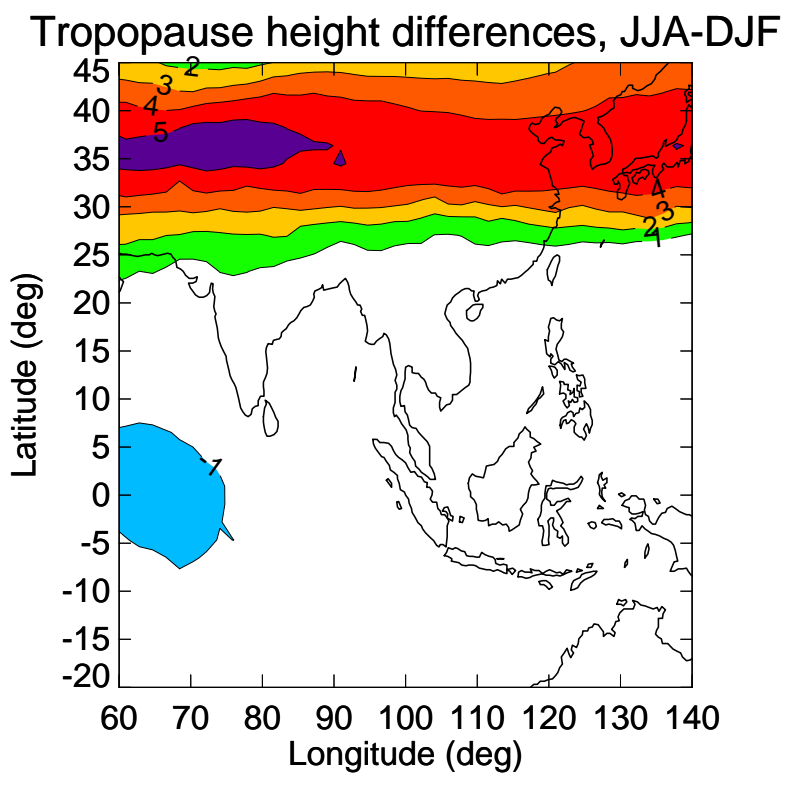

Problems regarding the tropospheric $\mathrm{O}_{3}$ residual method

A. T. J. de Laat and

I. Aben

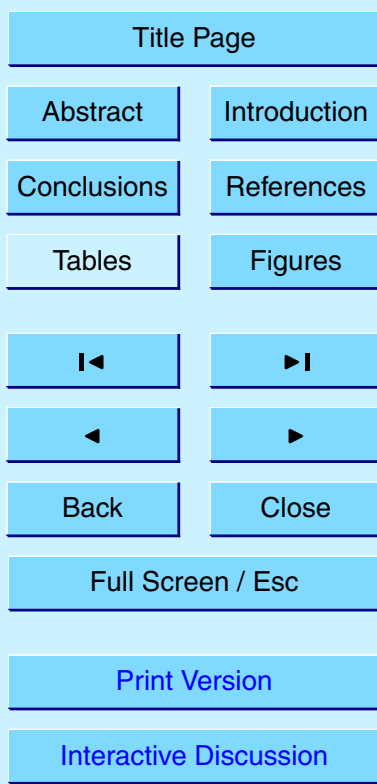

Fig. 3. Mean tropopause height differences $(\mathrm{km})$ between the seasons DJF and JJA derived from the ECHAM model simulation for 1996. 


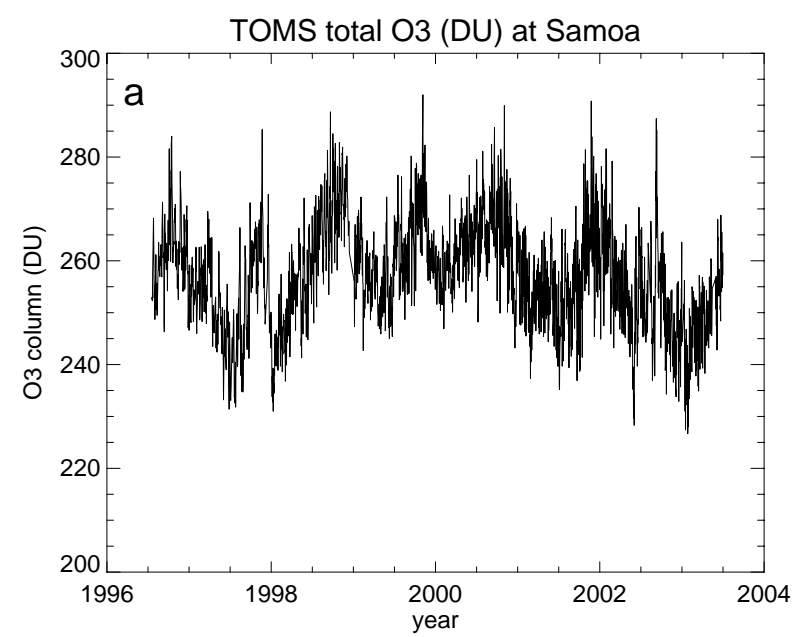

ACPD

3, 5777-5802, 2003

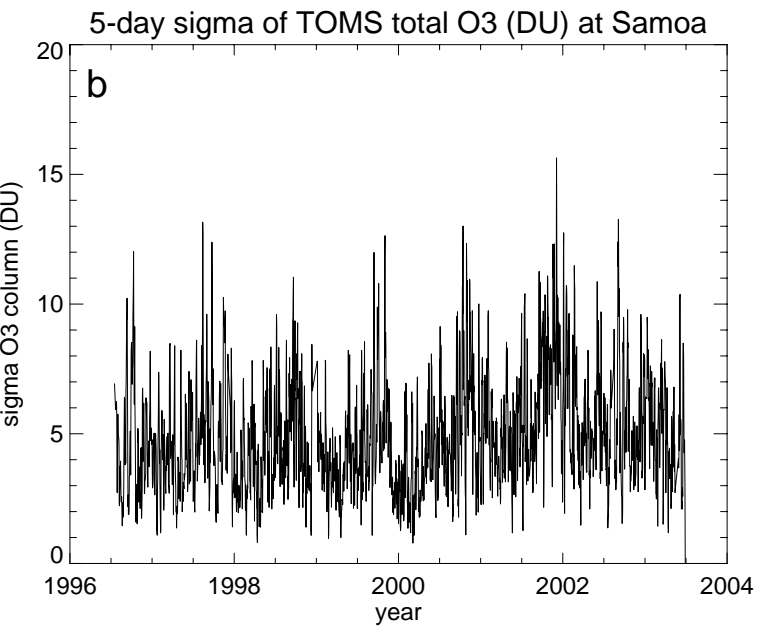

\section{Problems regarding the tropospheric $\mathrm{O}_{3}$ residual method}

A. T. J. de Laat and

I. Aben

Title Page

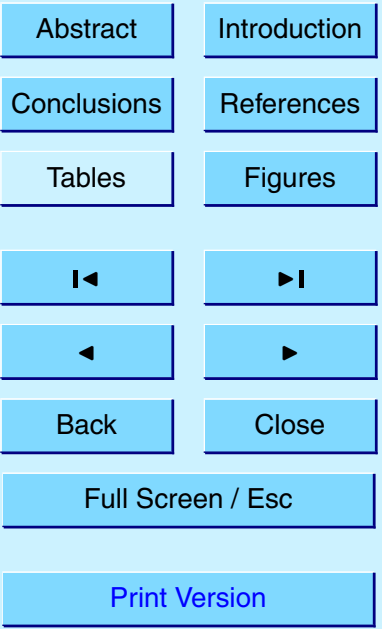

Interactive Discussion

Fig. 4. TOMS total $\mathrm{O}_{3}$ column (DU) measurements over Samoa $\left(14^{\circ} 15^{\prime} \mathrm{S}, 170^{\circ} 34^{\prime} \mathrm{W}\right)$ for the period 1996-2004, and the corresponding five-day standard deviation of the total $\mathrm{O}_{3}$ columns. 


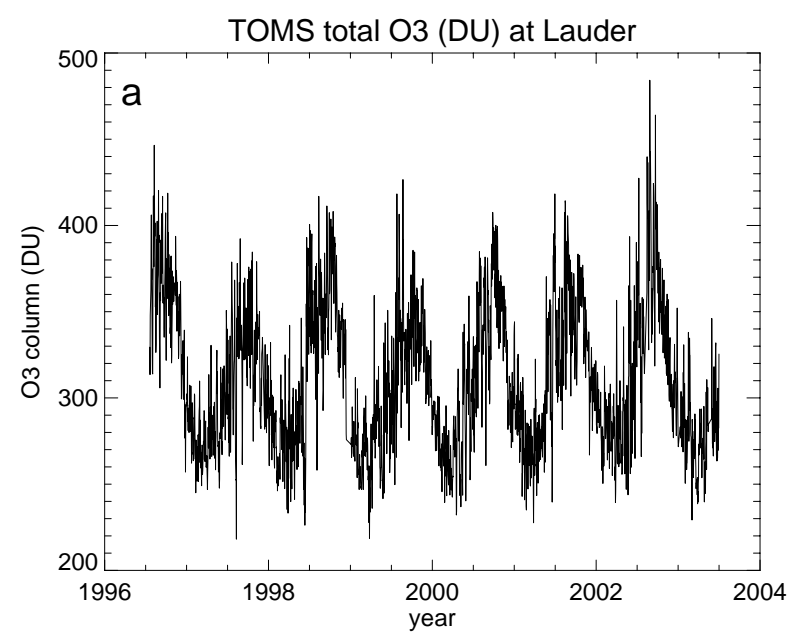

ACPD

3, 5777-5802, 2003

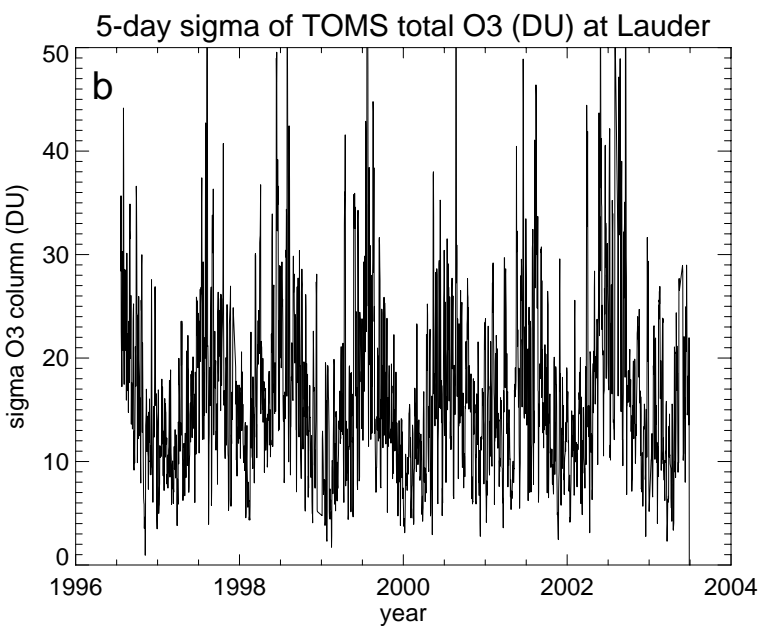

Problems regarding the tropospheric $\mathrm{O}_{3}$ residual method

A. T. J. de Laat and

I. Aben

Title Page

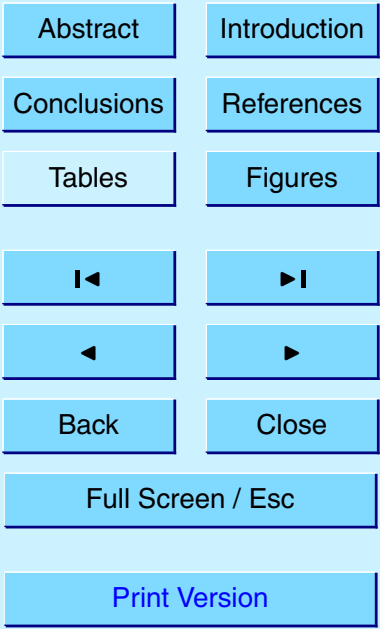

Interactive Discussion

Fig. 5. As Fig. 4 but for Lauder, New Zealand $\left(45^{\circ} 02^{\prime} \mathrm{S}, 169^{\circ} 40^{\prime} \mathrm{W}\right)$.

(c) EGU 2003 


\section{ACPD}

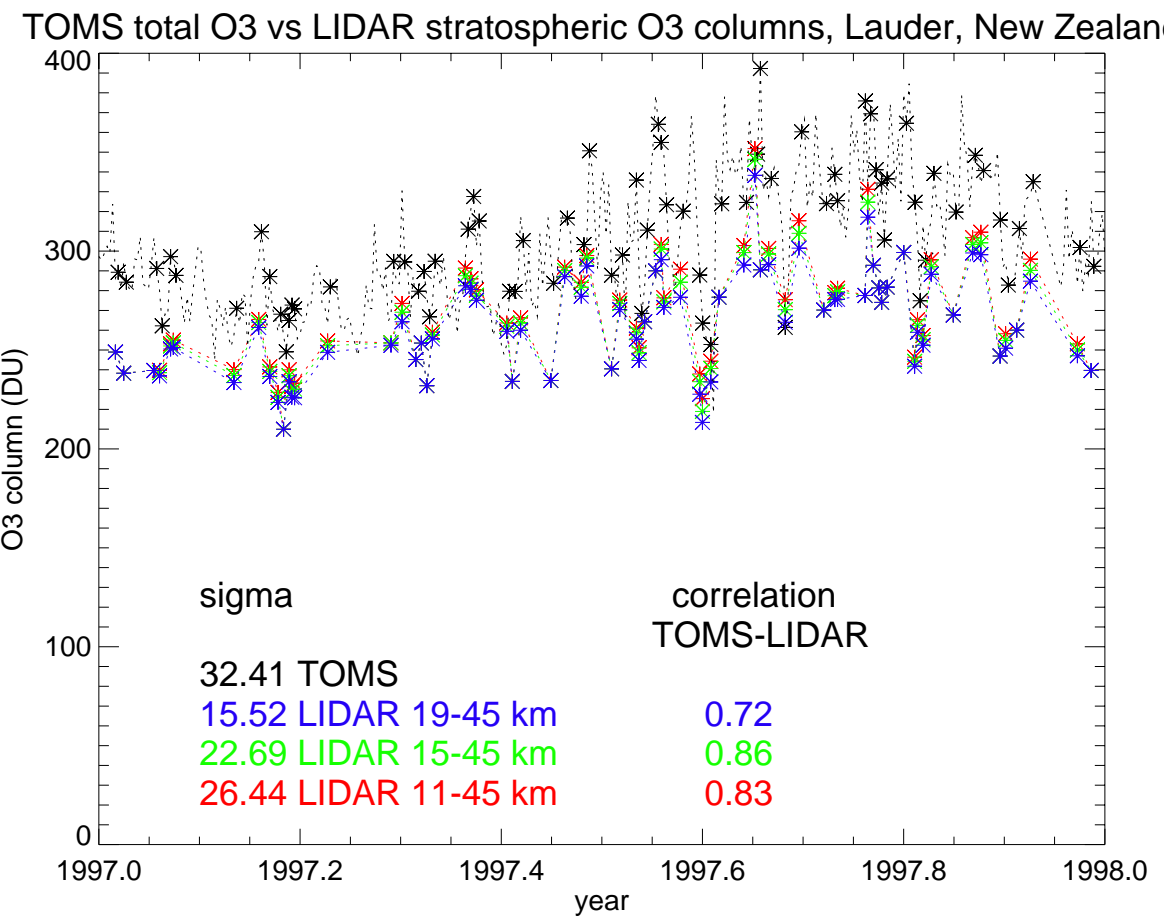

3, 5777-5802, 2003

Problems regarding the tropospheric $\mathrm{O}_{3}$ residual method

A. T. J. de Laat and

I. Aben

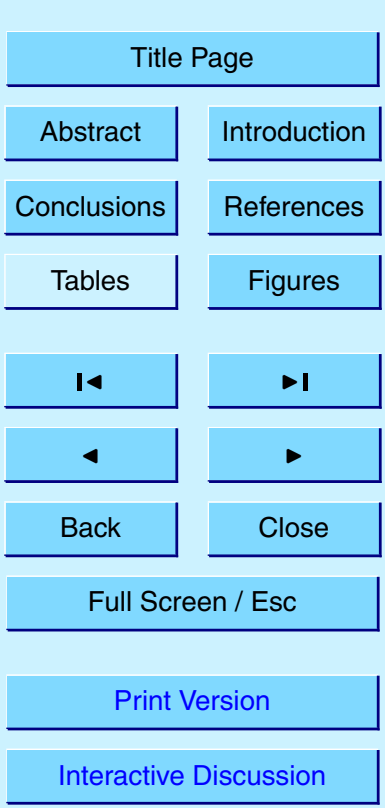

Fig. 6. $\mathrm{O}_{3}$ column measurements (DU) over Lauder, New Zealand for 1997. $\mathrm{O}_{3}$ columns from lidar measurements were calculated for the altitude ranges $11-45 \mathrm{~km}$ (red line), $15-45 \mathrm{~km}$ (green line) and $19-45 \mathrm{~km}$ (blue line). Total $\mathrm{O}_{3}$ column measurements from TOMS are denoted by the black dotted line, with the collocations with lidar measurements indicated by the asterixes. Indicated are also the values of standard deviation of the lidar and TOMS measurements, and the correlations between the lidar $\mathrm{O}_{3}$ columns and TOMS total $\mathrm{O}_{3}$ column measurements.

Interactive Discussion

(C) EGU 2003 